UDC 622.271

B. Yu. Sobko, Dr. Sc. (Tech.), Prof., orcid.org/0000-0002-6872-8458,

O. V. Lozhnikov, Cand. Sc. (Tech.), Assoc. Prof., orcid.org/0000-0003-1231-0295
DOI: $10.29202 /$ nvngu/2018-3/1

National Mining University, Dnipro, Ukraine, e-mail: sobko. boris.nmu@gmail.com

\title{
DETERMINATION OF CUT-OFF WALL COST EFFICIENCY AT MOTRONIVSKYI PIT MINING
}

Purpose. The economic efficiency definition of cut-off walls in rocks at the flooded Motronivskyi mining site of Malyshevskyi deposit taking into account the environmental aspects of the problem.

Methodology. For determination of possible technological solutions to reduce the inflow of groundwater into the pit used, methods of analysis and systematization were used. While selecting the indexes of evaluation to establish the effectiveness of cut-off walls in rocks analytical method was used. Determination of the mining and preparatory work volume for construction of tranches for placing waterproof materials was performed by graphic method. Substantiation of rational application of cut-off walls in rocks at Motronivskyi mining site of Malyshevskyi deposit was made using techno-economic analysis.

Findings. Analysis of modern technological solutions aimed at reducing the volume of inflow of groundwater into the pit was conducted. Method for determining an application field for cut-off walls at a flooded mining pit which takes into account the cost of draining the pit and decrease in the environmental damage to the environment is developed. Technical and economic performance of buildings cut-off wall at Motronivskyi pit mining that allows evaluating the technology effectiveness was set.

Originality. Dependence of the required economic effect at the construction of cut-off walls in rocks on the inflow of groundwater into the pit for the geological and hydrogeological conditions at mining Motronivskyi pit is determined.

Practical value. Methods for determining an application area of cut-off walls at mining flooded pits allows estimating the cost efficiency of using cut-off walls in rocks at mining flooded fields, taking into account mining-geological and hydrogeological conditions of occurrence.

Keywords: flooded deposits, surface mining, cost efficiency, cut-off walls

Introduction. The development of mineral deposits by the surface mining method has a significant impact on the environment, including the water balance of the mining region. The total area of single pit excavations can reach several thousand hectares, which must be continuously dried for safe mining operations [1].

In turn, work on the drainage of the field is associated with drilling a large number of filtration wells, through which groundwater is pumped [2]. The complex of preparation works associated with the drainage of the deposit [3] has a direct effect on the state of the aquifers in the surface mining area [4].

Another option to prevent groundwater from entering to the pit is construction of cut-off walls in rocks that consist of waterproof materials [5]. However, the construction and use of cut-off walls at the surface mining deposits assumes a large volume of mining and construction work, which requires significant capital costs, which cannot always be justified.

In this regard, it is urgent to establish the field of application of cut-off walls at the development of watered pits taking into account the environmental aspects of the problem.

Analysis of previous research. The technology of reducing water inflow into the working area of the pit involves constructing one deep trench with a small width and a closed contour and placing various waterproof materials in it afterwards. However, these works con-

(C) Sobko B. Yu., Lozhnikov O. V., 2018 cerned only the development of brown coal deposits with soft loose rocks, which were easily excavated [6]. As the research results have shown, cut-off walls are very effective for protecting open-cast mine from groundwater, as evidenced by their widespread use in Germany [7].

The construction of the trench, in which the cut-off wall is located, is carried out by a special trencher equipped with elongated working equipment on a rigid or cable fastening. The development and production of trencher machines began in the middle of the past century and has been developing intensively till our time. The leaders in the manufacture of these machines are the countries of Europe [8] and Japan [9].

Over the time this experience has been used by many European countries, as well as the United States, and has been praised as one of the effective measures to prevent water inflow into the pit which reduces the costs of draining the field deposit and maintains the groundwater balance in the region [5].

Unsolved aspects of the problem. The analysis of existing research works does not allow making specific recommendations on the use of water-proof walls in practice for other watered deposits, for example, for flooded placer deposits of titanium-zirconium ores (Motronivsko-Annovskyi placer deposits), where the ore is a zero-water quicksand. The technical and economic field of technical solutions application to prevent groundwater entering the pit is not sufficiently substantiated in these studies. Therefore, the determination of 
the rational application field for cut-off walls in conditions of surface mining flooded placer deposits is an urgent task.

Objectives of the article. The substantiation of the effective application of cut-off walls in soft rocks can be achieved by developing a methodology for determining the economic efficiency of their construction in the conditions of mining watered deposits taking into account the environmental aspects of the problem. This methodology should include the basic hydrogeological, technological, environmental and economic parameters that affect the mining enterprise operation.

Presentation of the main research. The construction of cut-off walls in rocks is divided into two successive processes. The first process consists in drilling a vertical trench along the perimeter of the upper pit contour with a given depth of $100 \mathrm{~m}$. This width, as a rule, does not exceed one meter. The depth of the cut-off wall during the construction corresponds to the level of the waterproof horizon which is located under the ore bed to prevent water from entering the pit from the bottom.

The second technological process involves filling and tamping the trench with waterproof materials. The choice of waterproofing material and mining equipment for trenching is described in [5] and is given in Table 1.

Each type of filler waterproof material for constructing cut-off walls (Table 1) has a characteristic chemical composition, physical and mechanical properties that affect waterproof efficiency of the residual pit space, as well as the construction costs, which should be taken into account while performing calculations [10].

To determine the economic feasibility of constructing a cut-off wall in rocks the technological parameters of the trench constructing process [11] and placing a waterproofing material in it were investigated.

During the construction of cut-off walls, significant costs are caused both by the construction of deep trenches and by the filling of trenches with the grouting mortar materials. The scope of work on the construction of the cut-off wall will depend on the size of the pit along the surface and its depth. In general terms, the expres-

Table 1

The choice of filler waterproof material during the construction of a cut-off wall in rocks depending on the type of mining equipment

\begin{tabular}{|c|c|c|c|c|}
\hline \multirow[b]{2}{*}{$\begin{array}{c}\text { Type of filler waterpro of } \\
\text { material }\end{array}$} & \multicolumn{4}{|c|}{ Excavation method } \\
\hline & 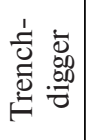 & 它 & 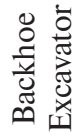 & 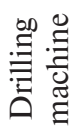 \\
\hline Regular concrete & + & + & - & + \\
\hline Plastic concrete & +- & +- & - & -+ \\
\hline Cement-bentonite solution & +- & +- & + & - \\
\hline Soil-bentonite solution & - & - & ++ & - \\
\hline Soil-cement-bentonite solution & -+ & -+ & + & - \\
\hline
\end{tabular}

* “_” does not apply, “-+" - rarely used, “+ - " - application is possible,"," - applied, “++" - often used sion of the trench volume can be written in the following form, $\mathrm{m}^{3}$

$$
V_{T P}=2\left(L_{K}+W_{K}+4 K\right) \cdot\left(H_{K} \pm \Delta Z\right) \cdot W_{T P}
$$

where $L_{K}$ is the length of the pit, m; $W_{K}$ is the width of the pit, $\mathrm{m} ; K$ is the distance between crest of upper pit bench and the cut-off wall, from $30 \mathrm{~m} ; H_{K}$ is the pit depth, m; $\Delta Z$ is the distance between the soil of the mineral deposit bed to the lower $(+)$ or bed surface to the upper (-) waterproof layer, $\mathrm{m} ; W_{T P}$ is the width of the trench, $\mathrm{m}$.

The construction costs for cut-off wall are calculated on the basis of the volumes (1) and the physical and mechanical properties of the overburden rocks. The costs are determined according to the expression, UAH

$$
Z_{B C}=V_{T P} \cdot C_{B C}
$$

where $C_{B C}$ is the cost of construction the trench and filling it with waterproof materials, $\mathrm{UAH} / \mathrm{m}^{3}$.

Analysis of the world experience in constructing cutoff walls in rocks [9] allows establishing that the cost of $C_{B C}$ per device of $1 \mathrm{~m}^{3}$ of this design is in the range from 65 to $2690 \$ / \mathrm{m}^{3}$. The difference in the cost of the construction of cut-off walls is due to the strength of the drilled rocks and the type of filler waterproof material [9]. When mining a rock with strength up to $30 \mathrm{MPa}$, the cost of constructing cut-off walls does not exceed $720 \$ / \mathrm{m}^{3}$. The change in the cost of constructing cut-off walls in loose rocks from 65 to $720 \$ / \mathrm{m}^{3}$ is explained by the depth of the trench. The minimum cost of the cut-off wall device is achieved by operating the backhoe excavator to a depth up to $22 \mathrm{~m}$.

At the construction of cut-off walls in the lignite deposits of Germany in the Lausitsa region, significant isolation of the pit working zone from the water from aquifers is achieved, but still some volumes of the water continues to flow into the worked-out space [5].

After the construction of the cut-off wall, the groundwater continues to enter the pit in a very limited amount. This can also be explained by the fact that to reduce the process cost in the construction of this wall in Germany, non-expensive soil-bentonite and soil-cement-bentonite solutions are used rather than concrete plugging solutions (Table 1).

That is why the effectiveness of the cut-off wall construction can be estimated by the level of groundwater inflow reduction into the worked-out pit space. Consequently, the higher efficiency of the cut-off wall use is, the lower the permeability of groundwater to the pit is.

During the technical and economic assessment of the cut-off wall construction effectiveness it is proposed to use the term "coefficient of cut-off wall efficiency". This coefficient reflects the change of water inflow into the pit when installing a cut-off wall. The coefficient of cut-off wall efficiency can be determined according to the following expression

$$
v_{C T}=\frac{F w-F^{\prime} w}{F w},
$$

where $F_{W}$ is the total volume of water flowing from the aquifers to the pit before the construction of the cut-off 
wall, $\mathrm{m}^{3} / \mathrm{h} ; F_{W}^{\prime}$ is the same, after the construction of the cut-off wall, $\mathrm{m}^{3} / \mathrm{h}$.

It follows from expression (3) that with an efficiency coefficient of the cut-off wall $v_{C T}=0$, the volume of groundwater water inflow into the pit will be the same as before the construction of the cut-off wall, and if $v_{C T}=1$, the water inflow into the pit will cease. Further this coefficient can be applied during the determination of the construction economic efficiency of such walls in pits.

In addition to a significant reduction in operating costs for the diversion of groundwater from the pit working area, cut-off walls significantly reduce the area of the depression funnel, as well as protect the landscape from large-scale drainage. In general, the economic efficiency of the cut-off wall construction in the pit (2) can be achieved at the following condition

$$
Z_{B C}<\sum_{i=1}^{n} F_{W i} \cdot C_{W i}-\sum_{i=1}^{n} F_{W i}^{\prime} \cdot C_{W i}+\sum_{i=1}^{n} E_{i}
$$

where $i$ is the year of deposit development, $n$ is the number of deposit development years, $C W$ is the cost of water removal from the pit, $\mathrm{m}^{3} / \mathrm{UAH} ; E$ is saving from reducing the environmental damage associated with the deposit drainage, UAH.

When carrying out the research, it is assumed that the cost of water removal from $1 \mathrm{~m}^{3}$ from the pit $C_{W}$ will be equal before and after the installation of the wall. In this case, equation (4) will have the following form

$$
V_{T P} \cdot C_{B C}<\sum_{i=1}^{n}\left(F_{W i}-F_{W i}^{\prime}\right) C_{W i}+\sum_{i=1}^{n} E_{i} .
$$

Substituting expression (3) into expression (5), we determine the minimum efficiency coefficient value of the cut-off wall for the determination of its use expediency

$$
v_{C T . M I N}=\frac{V_{T P} \cdot C_{B C}-\sum_{i=1}^{n} E_{i}}{\sum_{i=1}^{n} F_{W i} \cdot C_{W i}} .
$$

Therefore, the construction of a cut-off wall has an economic meaning when provided condition $v_{C T \text {.MIN }}<$ $<v_{C T} \leq 1$. The closer $v_{C T}$ is to 1 the higher the efficiency of the engineering structure application.

After determining the appropriateness of the efficiency of the cut-off wall in a pit use, efficiency of measures to reduce water inflow into the working area of the pit is checked by establishing the enterprise's benefit of the technology introduction according to the expression, UAH

$$
P=\sum_{i=1}^{n} F_{W i} \cdot C_{W i}-Z_{B C}-\sum_{i=1}^{n} F_{W i}^{\prime} \cdot C_{W i}+\sum_{i=1}^{n} E_{i} .
$$

Taking into account the efficiency coefficient of the cut-off wall (3), expression (6) can be represented in the form, UAH

$$
P=\sum_{i=1}^{n} F_{W i} \cdot C_{W i} \cdot v_{C T}-Z_{B C}+\sum_{i=1}^{n} E_{i} .
$$

The resulted technique of economic efficiency definition of cut-off wall application at operation open-cast mines allows establishing expediency of their construction in view of expenses for pit drainage reduction and reduction in ecological damage to environment.

To approbate the proposed methodology, as an example, the existing Motronivskyi pit is considered where the watered deposit of titanium-zirconium ores is developed. When solving the task, initial data are taken: the volume of the trench for the cut-off wall construction and the groundwater inflow into the pit. In accordance with the initial data the feasibility of a cut-off wall constructing in a given pit is established.

First of all, the cost of constructing a cut-off wall in Motronivskyi pit is determined according to expressions (1) and (2). It is mainly influenced by the length, depth and width of the preparatory trench. When performing calculations, the depth of the trench is assumed equal to $60 \mathrm{~m}$, which corresponds to the depth of Motronivskyi pit. As filling materials, bentonite solution, cementbentonite solution and ordinary concrete were taken (Table 1). Since the mining rocks under the conditions of Motronivskyi pit are loose, the cost of constructing the wall will not exceed $720 \$ / \mathrm{m}^{3}$ [5]. The established dependences of constructing a cut-off wall costs on its length and the type filler material are shown in Fig. 1.

As can be seen from the graphs shown in Fig. 1 the dependence of the wall building cost in the pit has a linear dependence on its pit length. The length of the wall corresponding to the perimeter of Motronivskyi pit is $6200 \mathrm{~m}$. The length of the wall construction in the pit is 33.8, 101.5, 169.3 million Euros for the bentonite, cement-bentonite solutions and ordinary concrete, respectively.

The next stage of the research is to determine the reduction of water inflow volumes in the pit with different coefficients of cut-off walls efficiency, according to the expression (3).

In carrying out the researches the initial data are the hydrogeological conditions for the mining Motronivs-

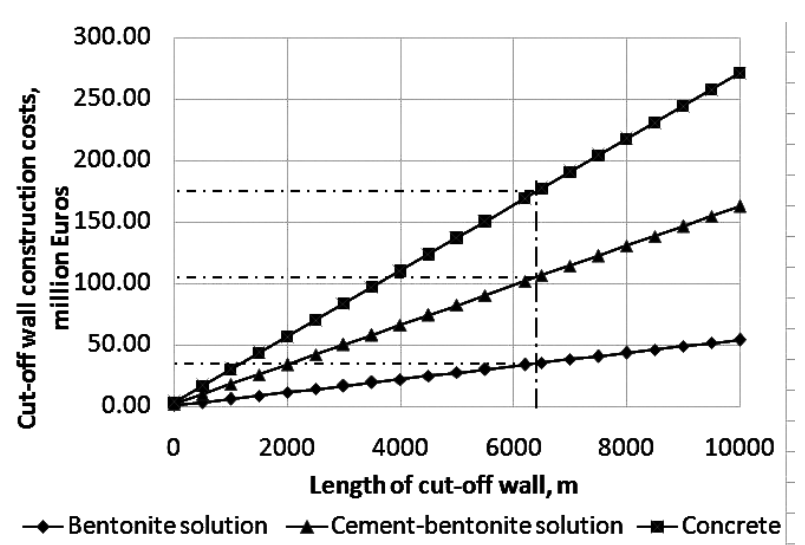

Fig. 1. Dependence of the constructing costs of a cut-off wall in rocks on its length and type of filler material with a pit depth $H_{k}=60 \mathrm{~m}$ 
ko-Annovskyi placer deposit in which the water inflow into the pit varies between $350-900 \mathrm{~m}^{3} / \mathrm{h}$ depending on the calculation method [10]. The following efficiency coefficients of cut-off walls were adopted during the research: for a bentonite solution -0.9 ; cement-bentonite solution -0.95 ; of concrete -1.0 . The research results of the dependence of water inflow into the pit on the coefficient of cut-off walls efficiency and water inflow into the pit are shown in Fig. 2.

The results of the studies shown in Fig. 2 also demonstrate a linear dependence of the water inflow into the pit on the coefficient of the cut-off walls efficiency. At the same time the change in this indicator in the range 0.9-1.0 has no significant effect on the reduction of water inflow into the pit. At the same time, previous studies showed that the type of cut-off walls material has a significant impact on the cost of their construction.

After determining the constructing cost of the cutoff wall and the effect of the wall efficiency factor on reducing the water inflow into the pit, the value of decreasing the annual costs for the deposit dewatering according to the expression (4) is established. This allows determining the construction effectiveness of the cut-off wall in the pit, by comparing the costs of its construction and saving money by reducing the drainage of the pit. At the calculations the cost of water drainage work in the pit was taken equal to $1.76 \mathrm{UAH} / \mathrm{m}^{3}$ [12]. Dependencies in the reduction of annual costs for deposit drainage on the effectiveness coefficient of cut-off walls and water inflow into the pit are presented in Fig. 3.

The data shown in the graphs (Fig. 3) allows establishing that a reduction of annual costs for the deposit drainage with an hourly water inflow of $900 \mathrm{~m}^{3} / \mathrm{h}$ with the efficiency coefficient of the water-proof wall of 0.9 , 0.95 and 1 is equal to 447.2 thousand Euros, 472.1 thousand Euros and 496.9 thousand Euros, respectively.

After determining the annual costs and saving money for the deposit drainage, the total savings from the construction of the cut-off wall during the pit operation are calculated. The average duration of a pit life during the mining is 25 years, therefore, for this period the economic efficiency of the cut-off wall construction in the pit is calculated.

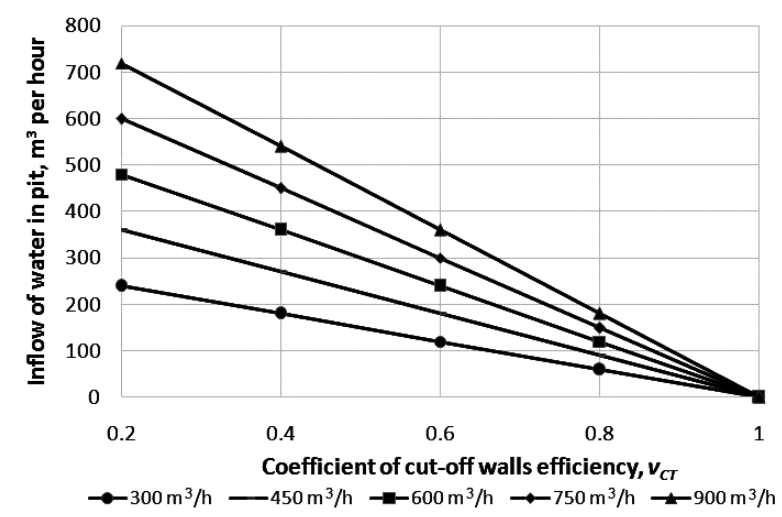

Fig. 2. Dependence of water inflow into the pit on the coefficient of cut-off walls efficiency and water inflow into the pit

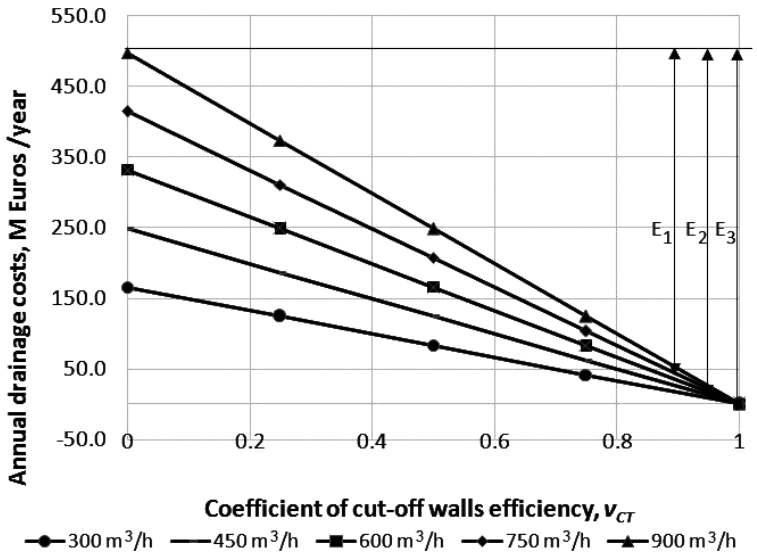

Fig. 3. Determination of cost reduction for the pit drainage with increasing efficiency coefficient of waterproof walls:

$E_{1} E_{2}$ and $E_{3}-$ savings on the costs of the deposit drainage with efficiency coefficient of 0.9, 0.95 and 1.0, respectively

In addition, while calculating the feasibility of construction of a water-resistant wall in expression (4), the parameter of economy saving from reducing environmental damage associated with the deposit drainage was used. Accounting for this parameter is important due to the fact that in certain cases, the construction of a cutoff wall will be much more expensive than the amount of saved funds from reducing the volume of water inflow into the pit. Therefore, economic efficiency can be achieved due to the additional effect caused by a decrease in the impact of pit exploitation on the water basin of the mining region.

The conducted research studies on the establishment of a rational application field of cut-off walls at the development of watered deposits have made it possible to determine the permissible hydrogeological parameters for their effective application. As in previous studies, bentonite solution, cement-bentonite solution and ordinary concrete were taken as a material for cut-off walls.

According to research results, even when choosing the cheapest filler waterproof material, which is bentonite solution, the cost of building a cut-off wall at Motronivskyi pit will amount to 33.8 million Euros. While the cost savings for the largest water inflow are 447.2 thousand Euros per year or 11.2 million Euros over 25 years of the pit exploitation. Therefore, the effectiveness of the use of a cut-off wall in the mining conditions of Motronivskyi pit can be achieved only by obtaining additional savings from the environmental effect.

Fig. 4 shows a graph of the dependence of the necessary economic effect on the prevention of environmental damage caused by surface mining to the water balance of the region and the environment on the ground water inflow level into the residual pit space that describes the feasibility of using a cut-off wall in the pit.

The dependence shown in Fig. 4 will allow establishing the minimum necessary economic effect from reducing the damage to the environment due to the cut-off wall construction, which is required for the proposed 


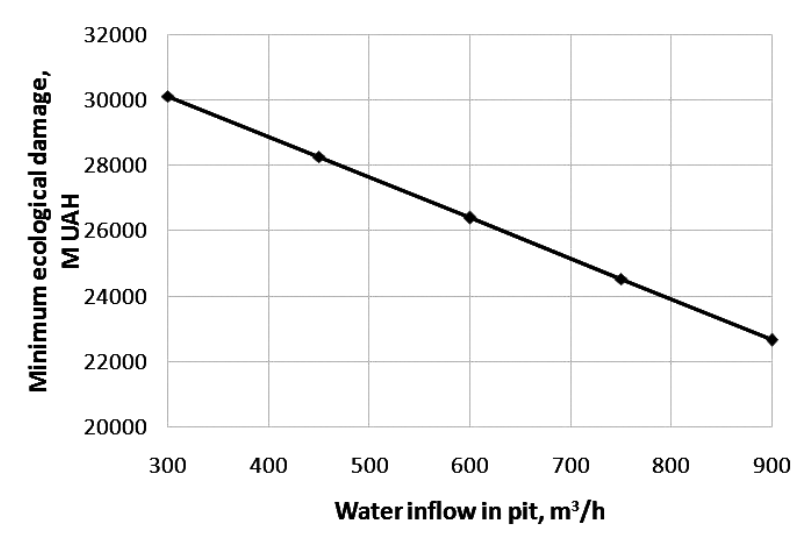

Fig. 4. Dependence of the ecological effect necessary on the cut-off wall construction while developing Motronivskyi pit on the groundwater inflow into the pit

technology implementation. As can be seen from the graph shown in Fig. 4 for 25 years of the pit exploitation the effectiveness of the cut-off wall construction can be achieved at the minimum reduction of environmental damage of 22.6-30.1 million Euros. At the same time, with the increase in water inflow into the pit the need for saving from the ecological effect decreases. This proves that with increasing water inflow into the pit the technology of cut-off walls constructing will be effective even with minimal reduction of environmental damage.

Conclusions and recommendations for further research. Conducted research studies have shown that the most cost-effective purpose for Motronivskyi pit is the cut-off wall in the rocks that is made with bentonite clay. It is established that a significant impact on the efficiency of the cut-off wall construction is rendered by a water inflow into the pit per hour. If the water inflow into the pit decreases from 900 to $300 \mathrm{~m}^{3}$ per hour, the necessary economic effect from reducing the negative impact mining operations on the environment of the region should increase by 7.5 million Euros during the pit exploitation time. However, these are pit fields with large water inflows and small area sites that show potential for the use of cut-off walls.

Under the conditions of Motronivskyi pit exploitation with a maximum water inflow to $900 \mathrm{~m}^{3}$ per hour for 25 years pit life cycle the total cost of the cut-off wall construction (33.8 million Euros) will save 11.2 million Euros. Therefore, the use of this technology can be effective only if damage by surface mining on environment exceeds 22.6 million Euros over 25 years pit life cycle (0.9 million Euros per year).

\section{References.}

1. Sobko, B.Y., Laznikov, O.M., Haidin, A.M. and Lozhnikov, O. V., 2016. Substantiation of rational mining method at the Motronivskyi titanium-zirconium ore deposit exploration. Naukovyi Visnyk Natsionalnoho Hirnychoho Universytetu, 156, pp. 41-49.

2. Bätz, K. D. Efficient drainage at Vattenfall Europe's opencast lignite mines in Lusatia. Vattenfall Europe [pdf], pp. 15-17. Available at: <http://www.kaeser.sk/ sub/kaeser.sk/images/Perfect\%20 Partnership\%20
-\%20Mining\%20\&\%20Conservation.pdf> [Accessed 28 March 2017].

3. Groundwater Engineering, 2016. Dewatering for Basement Construction. Available at: <https://www. groundwatereng.com/blog/2016/03/dewatering-forbasement-construction $>$ [Accessed 25 October 2017].

4. Pluntke, T., Schwarzak, S., Kuhn, K., Lünich, K., Adynkiewicz-Piragas, M., Otop, I. and Miszuk, B., 2016. Climate analysis as a basis for a sustainable water management at the Lusatian Neisse. Meteorology Hydrology and Water Management. Research and Operational Applications, 4(1), pp. 3-11.

5. Bruce, D. A., Dreese, T. L., Harris, M. C. and Heenan, D. M., 2012. Composite Cut-Off Walls for Existing Dams: Theory and Practice. In: Proceedings of the Fourth International Conference on Grouting and Deep Mixing. DOI: 10.1061/9780784412350.0102.

6. Du, Y.J., Fan, R.D., Liu, S.Y., Reddy, K. R. and Jin, F., 2015. Workability, compressibility and hydraulic conductivity of zeolite-amended clayey soil/calciumbentonite backfills for slurry-trench cutoff walls. Engineering Geology, 195, pp. 258-268.

7. Schwank, S., 2016. Cut-off Wall Technologies in Mining. In: C., Drebenstedt, M., Paul, eds. Mining Meets Water - Conflicts and Solutions. Freiberg: Medienzentrum of TU Bergakademie Freiberg [pdf], pp. 468-477. Available at: <https://www.imwa.info/docs/ imwa_2016/IMWA2016_Schwank_162.pdf> [Accessed 25 April 2017].

8. Lu, W., Zhao, D. and Wang, Y., 2015. The Effect of Excavation Dewatering and Supporting Structure Deformation on Soil Settlement. Electronic Journal of Geotechnical Engineering, 20(9), pp. 3955-3964.

9. Jasperse, B., Siepi, M. and Bruce, D. A. Excavated and backfilled cut-offs. Available at: <http://www.crcnetbase.com/doi/pdfplus/10.1201/b12974-5> [Accessed 15 March 2017].

10. Pavlichenko, A. V. and Kroik, A. A., 2013. Geochemical assessment of the role of aeration zone rocks in pollution of ground waters by heavy metals. Naukovyi Visnyk Natsionalnoho Hirnychoho Universytetu, 5, pp. 93-99.

11. Prokopenko, V. I. and Litvinov, Yu.I., 2017. Environmental oriented imperative of developing the opening technology and excavation of horizontal fields. Naukovyi Visnyk Natsionalnoho Hirnychoho Universytetu, 2, pp. $51-57$.

12. Haidin, A.M., Sobko, Yu. and Laznikov, A.M., 2016. Mining flooded deposits of titanium ores: Monograph. Dnipro: Lithographer.

\section{Оцінка економічної ефективності застосування водотривких стін у гірських породах в умовах Мотронівського кар'єра}

\section{Б. Ю. Собко, О. В. Ложніков}

Державний вищий навчальний заклад „Національний гірничий університет“, м. Дніпро, Україна, e-mail: sobko. boris.nmu@gmail.com

Мета. Визначення економічної ефективності використання водотривких стін у гірських породах 
в умовах розробки обводненої Мотронівської ділянки Малишевського родовища 3 урахуванням екологічних аспектів проблеми.

Методика. Для визначення можливих технологічних рішень зі зменшення водоприпливу підземних вод у кар'єр використані методи аналізу й систематизації. При виборі показників оцінки зі встановлення ефективності застосування водотривких стін у гірських породах використано аналітичний метод. Визначення обсягів гірничопідготовчих робіт при спорудженні траншей для розмішення водотривких матеріалів виконано з використанням графоаналітичного методу. Обгрунтування доцільності застосування водотривких стін у гірських породах в умовах розробки Мотронівської ділянки Малишевського родовища виконано з використанням техніко-економічного аналізу.

Результати. Виконано аналіз сучасних технологічних рішень, спрямованих на зменшення обсягів водоприпливу грунтових вод до кар'єра. Розроблена методика визначення області застосування водотривких стін при експлуатації обводнених кар'єрів, що враховує витрати на осушення кар'єру й скорочення екологічного збитку навколишньому середовищу. Встановлені техніко-економічні показники застосування водотривких стін в умовах розробки Мотронівского кар'єра, що дозволяють оцінити ефективність даного технологічного рішення.

Наукова новизна. Встановлена залежність необхідного економічного ефекту від спорудження водотривкої стіни в гірських породах від водопритоку грунтових вод до кар'єра для гірничо-геологічних і гідрогеологічних умов розробки Мотроновского кар'єра.

Практична значимість. Методика визначення області застосування водотривких стін при експлуатації обводнених кар'єрів дозволяє оцінити економічну ефективність застосування водотривких стін у гірських породах при розробці обводнених родовищ з урахуванням гірничо-геологічних і гідрогеологічних умов залягання.

Ключові слова: обводнені родовища, відкрита розробка, економічна ефективність, водотривкі стіни

\section{Оценка экономической эффективности применения водоупорных стен в горных породах в условиях Мотроновского карьера}

\section{Б. Е. Собко, А. В. Ложников}

Государственное высшее учебное заведение „Национальный горный университет“, г. Днепр, Украина, e-mail: sobko.boris.nmu@gmail.com
Цель. Определение экономической эффективности использования водоупорных стен в горных породах в условиях разработки обводненного Мотроновского участка Малышевского месторождения с учетом экологических аспектов проблемы.

Методика. Для определения возможных технологических решений по уменьшению водопритока подземных вод в карьер использованы методы анализа и систематизации. При выборе показателей оценки по установлению эффективности применения водоупорных стен в горных породах использован аналитический метод. Определение объемов горно-подготовительных работ при сооружении выемок для размещения водоупорных материалов выполнено с использованием графоаналитического метода. Обоснование целесообразности применения водоупорных стен в горных породах в условиях разработки Мотроновского участка Малышевского месторождения выполнено с использованием технико-экономического анализа.

Результаты. Выполнен анализ современных технологических решений, направленных на уменьшение объемов водопритока грунтовых вод в карьер. Разработана методика определения области применения водоупорных стен при эксплуатации обводненных карьеров, которая учитывает затраты на осушение карьера и сокращение экологического ущерба окружающей среде. Установлены техникоэкономические показатели применения водоупорных стен в условиях разработки Мотроновского карьера, позволяющие оценить эффективность данного технологического решения.

Научная новизна. Установлена зависимость необходимого экономического эффекта от сооружения водоупорной стены в горных породах от водопритока грунтовых вод в карьер для горно-геологических и гидрогеологических условий разработки Мотроновского карьера.

Практическая значимость. Методика определения области применения водоупорных стен при эксплуатации обводненных карьеров позволяет оценить экономическую эффективность применения водоупорных стен в горных породах при разработке обводненных месторождений с учетом горно-геологических и гидрогеологических условий залегания.

Ключевые слова: обводненные месторождения, открытая разработка, экономическая эффективность, водоупорные стены

Рекомендовано до публікації докт. техн. наук А.Ю.Дріженком. Дата надходження рукопису 17.03.17. 